(c) American Dairy Science Association, 2007.

\title{
Lipolysis in Cheddar Cheese Made from Raw, Thermized, and Pasteurized Milks
}

\author{
D. K. Hickey, ${ }^{*}$ K. N. Kilcawley, ${ }^{* 1}$ T. P. Beresford, ${ }^{*}$ and M. G. Wilkinson† \\ ${ }^{*}$ Moorepark Food Research Centre, Teagasc, Moorepark, Fermoy, Co. Cork, Ireland \\ †Department of Life Sciences, University of Limerick, Castletroy, Limerick, Ireland
}

\begin{abstract}
The evolution of free fatty acids (FFA) was monitored over $168 \mathrm{~d}$ of ripening in Cheddar cheeses manufactured from good quality raw milk (RM), thermized milk $\left(\mathrm{TM} ; 65^{\circ} \mathrm{C} \times 15 \mathrm{~s}\right)$, and pasteurized milk $\left(\mathrm{PM} ; 72^{\circ} \mathrm{C} \times\right.$ $15 \mathrm{~s})$. Heat treatment of the milk reduced the level and diversity of raw milk microflora and extensively or wholly inactivated lipoprotein lipase (LPL) activity. Indigenous milk enzymes or proteases from RM microflora influenced secondary proteolysis in TM and RM cheeses. Differences in FFA in the RM, TM, and PM influenced the levels of FFA in the subsequent cheeses at $1 \mathrm{~d}$, despite significant losses of FFA to the whey during manufacture. Starter esterases appear to be the main contributors of lipolysis in all cheeses, with LPL contributing during production and ripening in RM and, to a lesser extent, in TM cheeses. Indigenous milk microflora and nonstarter lactic acid bacteria appear to have a minor contribution to lipolysis particularly in PM cheeses. Lipolytic activity of starter esterases, LPL, and indigenous raw milk microflora appeared to be limited by substrate accessibility or environmental conditions over ripening.
\end{abstract}

Key words: Cheddar cheese, lipolysis, heat treatment

\section{INTRODUCTION}

It is generally accepted that Cheddar cheeses made from pasteurized milk tend to develop a less intense flavor and ripen more slowly than cheeses made from raw milk (McSweeney et al., 1993; Shakeel-Ur-Rehman et al., 2000a,b). This outcome is thought to result from inactivation of indigenous milk enzymes and destruction of the thermolabile microflora by pasteurization.

The agents responsible for lipolysis in raw milk Cheddar cheese are indigenous milk lipoprotein lipase (LPL; EC 3.1.1.3.4), raw milk microflora, starter lactic acid bacteria, and nonstarter lactic acid bacteria (NSLAB;

Received July 4, 2006.

Accepted August 17, 2006.

${ }^{1}$ Corresponding author: kieran.kilcawley@teagasc.ie
Collins et al., 2003; Beuvier and Buchin, 2004). In the northeastern United States and Canada, most Cheddar cheese is manufactured from high quality Grade A milk that has been thermized (Lau et al., 1991; Roy et al., 1997). Thermization is a generic description of a range of subpasteurization heat treatments $\left(57\right.$ to $68^{\circ} \mathrm{C} \times 10$ to $20 \mathrm{~s}$ ) that markedly reduce the number of spoilage bacteria in milk with minimal heat damage (Stepaniak and Rukke, 2003).

Studies comparing Cheddar cheeses made from raw, pasteurized, and microfiltered milk (McSweeney et al., 1993), blends of raw and pasteurized milks (ShakeelUr-Rehman et al., 2000a), and raw and pasteurized cheese ripened at different temperatures (Shakeel-UrRehman et al., 2000b) indicate that higher levels of lipolysis in raw milk Cheddar cheeses may be due to differing growth rates of NSLAB. In cheeses made from raw milk, NSLAB populations increase and generally reach a plateau more rapidly compared with pasteurized milk cheeses. The NSLAB species in the resulting cheeses also appear to differ with severity of heat treatment of the milk (McSweeney et al., 1993; Roy et al., 1997; Beuvier and Buchin, 2004). The microflora of Cheddar cheese has been shown to comprise species other than NSLAB, including enterococci and psychrotrophic bacteria, which may also contribute to lipolysis in Cheddar cheese (Dovat et al., 1970; Ouattara et al., 2004).

Despite the numerous studies comparing lipolysis in raw and pasteurized Cheddar cheese, most studies report the extent of total lipolysis without supplying quantitative data on the profiles and levels of individual FFA generated during ripening. Moreover, there are no reports in the literature on the effect of thermization on lipolysis in Cheddar cheese. This study was therefore undertaken to provide quantitative data on lipolysis during ripening in Cheddar cheeses made from raw, thermized, and pasteurized milks.

\section{MATERIALS AND METHODS}

\section{Cheese Manufacture}

Lactococcus lactis ssp. lactis 303 obtained from Chr. Hansen Ireland Ltd. (Little Island, Co. Cork, Ireland) 
was grown overnight at $23^{\circ} \mathrm{C}$ in heat-treated $\left(95^{\circ} \mathrm{C}\right.$ for $30 \mathrm{~min}$ ) 10\% (wt/vol) reconstituted skim milk powder (Golden Vale Food Products Ltd., Co. Cork, Ireland). This strain was used as starter culture at a level of $1.5 \%$ (wt/wt).

Cheddar cheeses were manufactured in $500-\mathrm{L}$ vats on 3 separate occasions using milk obtained from the Friesian herd at the Dairy Production Centre, Moorepark, Ireland. For each cheese trial, approximately $1,500 \mathrm{~L}$ of milk was collected from the farm the day before manufacturing and held overnight at $4^{\circ} \mathrm{C}$. On the day of cheese manufacture the milk was heated to $\sim 30^{\circ} \mathrm{C}$, approximately $500 \mathrm{~L}$ was then passed through the pasteurizer and heated to $72^{\circ} \mathrm{C} \times 15 \mathrm{~s}$, and then pumped into the first vat for pasteurized milk (PM) cheeses. For thermized milk (TM) cheeses, $\sim 500 \mathrm{~L}$ of the raw milk was passed through the pasteurizer, heated to $65^{\circ} \mathrm{C} \times 15 \mathrm{~s}$, and pumped into the second vat. For the raw milk (RM) cheeses, the milk was pumped through the pasteurizer at ambient temperature and into the third vat. Before cheese manufacture, milk from the herd was analyzed to ensure the absence of Escherichia coli, fecal streptococci, Salmonella spp. and Listeria monocytogenes. Milks were not standardized for cheese making. Cheeses were manufactured using conventional cheese-making methods; curd was cooked to $38.5^{\circ} \mathrm{C}$, pitched at $\mathrm{pH} 6.15$, milled at $\mathrm{pH} 5.35$, and salted at $2.7 \%(\mathrm{wt} / \mathrm{wt})$. All practical precautions were undertaken during manufacturing to prevent cross-contamination between vats. Cheeses were ripened at $8^{\circ} \mathrm{C}$ for $168 \mathrm{~d}$ and sampled at $14 \mathrm{~d}$ of ripening for compositional analysis; all other analyses were carried out at d 1, 14, 28, 56, 112, and 168 .

\section{Chemical Composition of Milk}

Milks of all types were analyzed for fat (IDF, 1996), protein (IDF, 2001), and casein (IDF, 2004). Lactose was measured on a Milkoscan 605 (Foss Electric, Hillerød, Denmark). All analyses were conducted in duplicate.

\section{Microbiological Quality of Milk}

Coliforms in RM, TM, and PM were enumerated on violet red bile agar (Oxoid, Basingstoke, UK), incubated at $30^{\circ} \mathrm{C}$ for $24 \mathrm{~h}$; total bacterial count (TBC) was evaluated on milk plate count agar (Oxoid) incubated at $30^{\circ} \mathrm{C}$ for $72 \mathrm{~h}$. Psychrotrophic bacterial count (PBC) was enumerated on milk plate count agar (Oxoid) incubated at $8^{\circ} \mathrm{C}$ for $10 \mathrm{~d}$, enterococci were enumerated on kanamycin esculin azide agar (Merck, Darmstadt, Germany) incubated at $37^{\circ} \mathrm{C}$ for $24 \mathrm{~h}$, and NSLAB were incubated anaerobically on LBS agar (Rogosa et al., 1951) at $30^{\circ} \mathrm{C}$ for $5 \mathrm{~d}$. Staphylococci were enumerated on Baird Parker agar (Merck) with egg yolk tellurite supplement (Merck) and incubated at $37^{\circ} \mathrm{C}$ for 48 h. Staphylococcus aureus were identified on Baird Parker agar as black colonies surrounded by a clear zone and that tested positive for coagulase using the staphylase test (Oxoid). Lipolytic bacteria were estimated on tributyrin, triolein, and butterfat agars (Merck) incubated at 8 and $30^{\circ} \mathrm{C}$ for 10 and $3 \mathrm{~d}$, respectively. Lipolytic colonies were identified as colonies surrounded by clear zones in an otherwise turbid culture medium. Somatic cell count of RM was measured on a Bentley Somacount 300 (Bentley Instrument Inc., Chaska, MN). All analyses were carried out in duplicate.

\section{Enzyme Activity of Milks}

Commercially available API-ZYM kits (BioMérieux, Marcy-L'Etoile, France) for semiquantitative assay of 19 enzyme activities were used to monitor the effect of the milk heat treatments on a range of enzyme activities. Raw milk, TM, and PM $(65 \mu \mathrm{L})$ were inoculated into API-ZYM strips according to the manufacturer's instructions and incubated at $37^{\circ} \mathrm{C}$ for $5 \mathrm{~h}$ before color was developed using ZYM A and ZYM B reagents. The intensity of color developed within 5 min was compared with the API-ZYM color reaction chart and the enzyme activity was graded from 0 to 5 . A value of 0 corresponded to negative reaction and 5 to a reaction of maximum intensity. All analysis was conducted in duplicate.

\section{Lipolytic Activity of Cheese Milks}

Aseptically drawn RM, TM, and PM samples with $0.05 \%$ added sodium azide, were incubated at $37^{\circ} \mathrm{C}$ for $15 \mathrm{~h}$ with agitation $(100 \mathrm{rpm})$. Individual $\mathrm{FFA}\left(\mathrm{C}_{4: 0}\right.$ to $\mathrm{C}_{18: 1}$ ) in milk samples were quantified before and after incubation by gas chromatograph flame-ionized detection according to the method described by Hickey et al. (2006). All analyses were conducted in duplicate.

\section{Cheese Composition}

Grated cheese samples were analyzed in duplicate for $\mathrm{pH}$, moisture, fat, salt, and total nitrogen as described by Hickey et al. (2006).

\section{Microbiological Analysis of Cheese}

Microbiological analysis of the cheese was carried out in duplicate at each sampling point. Starter lactic acid bacteria were enumerated on LM17 agar after $3 \mathrm{~d}$ at $30^{\circ} \mathrm{C}$ over the first $56 \mathrm{~d}$ of ripening (Terzaghi and Sandine, 1975). Nonstarter lactic acid bacteria, coliforms, 
enterococci, staphylococci, TBC, psychrotrophic bacteria, and lipolytic bacteria were enumerated periodically over the 168-d ripening period.

\section{Starter Autolysis in Cheese}

Autolysis of starter culture in cheese during ripening was monitored periodically over the first $56 \mathrm{~d}$ by assaying the juice for the activity of the intracellular enzyme lactate dehydrogenase (LDH, EC 1.1.1.27). Cheese juice was extracted from cheeses as described by Wilkinson et al. (1994) and assayed immediately for LDH activity by a modification of the method of Wittenberger and Angelo (1970) by measuring the decrease in absorbance at $340 \mathrm{~nm}$ (Spectronic Genesys 5 spectrophotometer, Milton Roy Company, Rochester, NY) resulting from the pyruvate-dependent oxidation of NADH in the presence of fructose-1,6 bis-phosphate. Results were expressed in LDH units, where one unit was defined as the amount of enzyme that catalyzes the oxidation of one micromole of NADH per minute per milliliter of cheese juice.

\section{Assessment of Proteolysis in Cheese During Ripening}

Proteolysis in cheeses was monitored by measuring the percentage of total $\mathrm{N}$ soluble at $\mathrm{pH} 4.6$ (pH 4.6SN) and in 5\% phosphotungstic acid (PTA-SN) and individual free amino acids (FAA) as described by Hickey et al. (2006). All analyses were conducted in triplicate.

\section{Assessment of Lipolysis in Cheese During Ripening}

Individual $\mathrm{FFA}\left(\mathrm{C}_{4: 0}\right.$ to $\left.\mathrm{C}_{18: 1}\right)$ in cheese samples were quantified by gas chromatograph flame-ionized detection according to Hickey et al. (2006). All analysis was conducted in triplicate.

\section{Statistical Analysis}

A randomized complete block design, which incorporated the 3 treatments (heat treatments) and 3 blocks (replicate trials), was used for analysis of the response variables relating to milk (chemical and FFA) and cheese composition. Analysis of variance was carried out using the GLM procedure of SAS (version 9.1.3, SAS Institute Inc., 2003) in which the effect of treatment and replicates were estimated for all response variables. Duncan's multiple-comparison test was used as a guide for pair comparison of the treatment means. The level of significance was determined at $P<0.05$.

A split-plot design was used to monitor the effect of treatment, ripening time, and their interaction on the response variables measured at regular intervals during ripening; that is, LDH activity, pH4.6-SN, 5\% PTASN, FAA, and FFA. The ANOVA for the split plot was carried out using the GLM procedure of SAS (SAS Institute, 2003). Statistically significant differences ( $P$ $<0.05$ ) between the different treatments were determined by Fisher's least significant difference test.

Data relating to enzyme activities monitored by APIZYM assay were not statistically analyzed but are included as observations.

\section{RESULTS AND DISCUSSION}

\section{Composition of Milks}

Heat treatment had no significant effect on the composition of RM, TM, and PM. The mean protein, fat, lactose concentrations, and casein number (casein $\mathrm{N} \times$ $100 /$ total N) were $3.6,3.9,4.5$, and $79 \%$, respectively (data not shown).

\section{Bacteriological Quality of Cheese Milks}

Raw milk was of good microbial quality: TBC and SCC were within normal ranges for Cheddar cheese manufacture (European Union, 1992; Table 1). In agreement with Gilmour et al. (1981), thermization reduced TBC, PBC, coliforms, enterococci, NSLAB, and staphylococci and eliminated coagulase-positive staphylococci. Similar to the findings of Driessen and Stadhouders (1975), lipolytic bacteria were not detected in TM (Table 1). In agreement with Beuvier et al. (1997) and Shakeel-Ur-Rehman et al. (2000a,b), pasteurization further reduced TBC, PBC, and NSLAB and eliminated coliforms, enterococci, and staphylococci. Very low numbers $(<1 \log \mathrm{cfu} / \mathrm{mL})$ of lipolytic bacteria were detected in PM, which was probably due to postpasteurization contamination.

\section{Enzymatic Activity of Milk}

Enzymatic activities of RM, TM, and PM are shown in Table 2. Similar to the results of Griffiths (1986), leucine arylamidase was completely inactivated by thermization, which also inactivated esterase activity. As expected, pasteurization completely inactivated alkaline phosphatase, an indictor of pasteurization (Stepaniak and Rukke, 2003), and also inactivated most enzyme activities that could be detected using the APIZYM kit.

\section{Cheese Composition}

Heat treatment of the milks had no significant effect on gross cheese composition, which was within the 
Table 1. Bacterial count (log cfu/mL) and SCC of raw (RM), thermized (TM), and pasteurized (PM) milks ${ }^{1,2}$

\begin{tabular}{llll}
\hline Bacteria enumerated & RM & TM & PM \\
\hline Total bacterial count & $4.34(0.50)$ & $3.70(0.92)$ & $2.82(0.72)$ \\
Coliforms & $1.96(0.52)$ & $0.20(0.35)$ & ND \\
Enterococci & $3.11(1.26)$ & $1.15(0.16)$ & ND \\
Psychrotrophic count & $4.21(0.75)$ & $2.88(1.81)$ & $1.49(0.66)$ \\
Nonstarter lactic acid bacteria & $2.32(0.52)$ & $0.67(0.50)$ & $0.08(0.14)$ \\
Total staphylococci & $2.34(1.06)$ & $0.17(0.29)$ & ND \\
Coagulase-positive staphylococci & $1.73(1.52)$ & ND & ND \\
Lipolytic count at 30 $0^{\circ} \mathrm{C}$ & & & \\
Triolein-hydrolyzing & ND & ND & $0.83(1.43)$ \\
Tributyrin-hydrolyzing & $1.96(2.01)$ & ND & ND \\
Butterfat-hydrolyzing & ND & & ND \\
Lipolytic count at $8^{\circ} \mathrm{C}$ & & ND & ND \\
Triolein-hydrolyzing & ND & ND & ND \\
Tributyrin-hydrolyzing & ND & & ND \\
Butterfat-hydrolyzing & $210 \times 10^{3}$ & & \\
SCC, cells/mL & &
\end{tabular}

\footnotetext{
${ }^{1}$ Numbers represent means $(\mathrm{SD} ; \mathrm{n}=3) ; \mathrm{ND}=$ Not detected.

${ }^{2}$ Higher SD than the means occurred when the microbial group was absent from 1 or 2 of the triplicate trials.
}

ranges recommended by Gilles and Lawrence (1973) for good quality Cheddar (Table 3).

\section{Bacteriological Quality of Cheeses}

Microbial counts in RM, TM, and PM cheeses during ripening are shown in Table 4. In agreement with previous studies (O'Donovan et al., 1996; Hickey et al., 2006; Sheehan et al., 2006), the viability of starter L. lactis

Table 2. Enzyme activity after heat treatment of raw (RM), thermized (TM), and pasteurized (PM) milks detected using the API-ZYM system $^{1}$

\begin{tabular}{llll}
\hline & \multicolumn{3}{c}{ Observed color intensity $^{2}$} \\
\cline { 2 - 4 } Enzyme activity & $\mathrm{RM}$ & $\mathrm{TM}$ & $\mathrm{PM}$ \\
\hline Alkaline phosphatase & 5 & 5 & 0 \\
Esterase $\left(\mathrm{C}_{4: 0}\right)$ & 2 & 0 & 0 \\
Esterase/lipase $\left(\mathrm{C}_{8: 0}\right)$ & 2 & 0 & 0 \\
Lipase $\left(\mathrm{C}_{14: 0}\right)$ & 0 & 0 & 0 \\
Leucine arylamidase & 2 & 0 & 0 \\
Valine arylamidase & 0 & 0 & 0 \\
Cystine arylamidase & 0 & 0 & 0 \\
Trypsin & 0 & 0 & 0 \\
$\beta$-Chymotrypsin & 0 & 0 & 0 \\
Acid phosphatase & 4 & 4 & 1 \\
Naphthol-AS-bi-phosphohydrolase & 4 & 3 & 1 \\
$\alpha$-Galactosidase & 0 & 0 & 0 \\
$\beta$-Galactosidase & 0 & 0 & 0 \\
$\beta$-Glucuronidase & 0 & 0 & 0 \\
$\alpha$-Glucosidase & 0 & 0 & 0 \\
$\beta$-Glucosidase & 0 & 0 & 0 \\
N-Acetyl- $\beta$-glucosaminidase & 0 & 0 & 0 \\
$\alpha$-Mannosidase & 1 & 0 & 0 \\
$\alpha$-Fucosidase & 0 & 0 & 0 \\
\hline
\end{tabular}

${ }^{1}$ Data presented are the means of triplicate trials.

${ }^{2}$ Color intensity: $0=$ negative reaction; $5=$ reaction of maximum intensity.
303 remained at $\sim 9 \log \mathrm{cfu} / \mathrm{g}$ during the early stages of ripening and was similar in all cheeses.

At $1 \mathrm{~d}$ of ripening, NSLAB numbers were 1.1, 1.9, and $4.2 \mathrm{log} \mathrm{cfu} / \mathrm{g}$ and increased rapidly over the first $56 \mathrm{~d}$ reaching 5.7, 6.0, and $7.6 \mathrm{log} \mathrm{cfu} / \mathrm{g}$ in PM, TM, and RM cheeses, respectively. After $56 \mathrm{~d}$, NSLAB reached a plateau in RM cheeses, whereas NSLAB continued to increase (albeit at a slower rate) in TM and PM cheeses. At $168 \mathrm{~d}$ of ripening, NSLAB populations had reached 7.2, 7.6, and 7.6 log cfu/g in PM, TM, and RM cheeses, respectively.

Low numbers of coliforms were present in all cheeses at $d 1$ and declined during ripening. Enterococcal populations remained relatively stable during ripening in all cheeses and at $168 \mathrm{~d}$ were present at 5.5, 4.0, and $1.0 \mathrm{log} \mathrm{cfu} / \mathrm{g}$ in RM, TM, and PM cheeses, respectively.

Table 3. Composition of Cheddar cheeses (\% wt/wt) made from raw (RM), thermized (TM), and pasteurized (PM) milks ${ }^{1}$

\begin{tabular}{lrrrr}
\hline & \multicolumn{3}{c}{ Cheese } \\
\cline { 2 - 4 } Composition $^{2}$ & RM & TM & PM & SED \\
\hline Moisture & $36.5^{\mathrm{a}}$ & $36.5^{\mathrm{a}}$ & $37.0^{\mathrm{a}}$ & 0.35 \\
Fat & $32.9^{\mathrm{a}}$ & $32.7^{\mathrm{a}}$ & $32.4^{\mathrm{a}}$ & 0.16 \\
Protein & $25.7^{\mathrm{a}}$ & $25.2^{\mathrm{a}}$ & $25.3^{\mathrm{a}}$ & 0.30 \\
Salt & $1.6^{\mathrm{a}}$ & $1.6^{\mathrm{a}}$ & $1.7^{\mathrm{a}}$ & 0.34 \\
S/M & $4.5^{\mathrm{a}}$ & $4.4^{\mathrm{a}}$ & $4.5^{\mathrm{a}}$ & 0.37 \\
FDM & $51.7^{\mathrm{a}}$ & $51.5^{\mathrm{a}}$ & $51.4^{\mathrm{a}}$ & 0.37 \\
MNFS & $54.4^{\mathrm{a}}$ & $54.2^{\mathrm{a}}$ & 54.7 & 0.52 \\
pH & $5.1^{\mathrm{a}}$ & $5.1^{\mathrm{a}}$ & $5.1^{\mathrm{a}}$ & 0.06 \\
\hline
\end{tabular}

${ }^{a}$ Values within rows not sharing a common superscript differ significantly, $P<0.05$.

${ }^{1}$ Data presented are the means of triplicate trials; SED = standard error of difference across the treatment means.

${ }^{2} \mathrm{~S} / \mathrm{M}=$ Salt in moisture; FDM = fat in DM; MNFS = moisture in nonfat substrates. 
Table 4. Starter, adventitious, and lipolytic bacterial counts (log cfu/g) present in Cheddar cheeses made from raw (RM), thermized (TM), and pasteurized (PM) milk during ripening ${ }^{1,2}$

\begin{tabular}{|c|c|c|c|c|c|c|c|c|c|c|}
\hline \multirow[b]{2}{*}{ Cheese } & \multirow[b]{2}{*}{$\begin{array}{l}\text { Ripening } \\
\text { time, d }\end{array}$} & \multirow[b]{2}{*}{ Starter } & \multicolumn{5}{|c|}{ Adventitious bacteria } & \multicolumn{3}{|c|}{ Lipolytic bacteria $^{3}$} \\
\hline & & & NSLAB $^{4}$ & Coliforms & Enterococci & $\begin{array}{l}\text { Total } \\
\text { staphylococci }\end{array}$ & $\begin{array}{l}\text { Coagulase- } \\
\text { positive } \\
\text { staphylococci }\end{array}$ & $\begin{array}{l}\text { Tributyrin, } \\
30^{\circ} \mathrm{C}\end{array}$ & $\begin{array}{l}\text { Triolein, } \\
30^{\circ} \mathrm{C}\end{array}$ & $\begin{array}{l}\text { Butterfat, } \\
30^{\circ} \mathrm{C}\end{array}$ \\
\hline \multirow[t]{4}{*}{$\mathrm{RM}$} & 1 & $9.26(0.58)$ & $4.21(0.59)$ & $2.98(1.45)$ & $4.45(0.18)$ & $5.01(0.07)$ & $4.34(0.11)$ & $4.59(3.32)$ & $\mathrm{ND}^{5}$ & ND \\
\hline & 14 & $9.20(0.28)$ & $5.66(0.63)$ & $3.19(0.10)$ & $5.31(1.38)$ & $5.15(0.57)$ & $4.48(0.03)$ & $3.31(1.02)$ & ND & ND \\
\hline & 28 & $9.17(0.18)$ & $6.49(0.45)$ & $2.90(0.21)$ & $5.53(0.91)$ & $4.90(0.04)$ & $4.56(0.13)$ & $3.46(0.65)$ & ND & ND \\
\hline & 56 & $9.08(0.28)$ & $7.58(0.73)$ & $2.40(0.10)$ & $5.42(1.32)$ & $4.95(0.06)$ & $3.09(2.68)$ & $4.12(0.31)$ & ND & ND \\
\hline \multirow[t]{6}{*}{ TM } & 1 & $9.44(0.55)$ & $1.94(1.06)$ & $1.43(1.49)$ & $2.77(0.20)$ & $2.87(1.01)$ & ND & $1.46(1.36)$ & ND & ND \\
\hline & 14 & $9.09(0.41)$ & $3.70(0.43)$ & $1.20(1.22)$ & $3.86(1.64)$ & $3.66(1.07)$ & ND & $1.37(1.42)$ & ND & ND \\
\hline & 28 & $9.03(0.33)$ & $4.82(1.11)$ & $1.31(1.26)$ & $4.03(1.39)$ & $3.51(1.50)$ & ND & $1.81(1.57)$ & ND & ND \\
\hline & 56 & $9.02(0.48)$ & $6.00(0.88)$ & $1.54(1.04)$ & $4.01(1.76)$ & $2.62(0.76)$ & ND & $1.74(1.54)$ & ND & ND \\
\hline & 112 & - & $7.41(0.36)$ & ND & 3.85 (1.78) & $3.16(0.42)$ & ND & $1.77(1.54)$ & ND & ND \\
\hline & 168 & - & $7.60(0.16)$ & ND & $3.96(1.67)$ & $1.47(1.69)$ & ND & $2.67(2.68)$ & ND & ND \\
\hline \multirow{2}{*}{ PM } & 112 & - & $5.71(1.21)$ & ND & $1.04(0.92)$ & ND & ND & $0.33(0.56)$ & ND & ND \\
\hline & 168 & - & $7.15(0.68)$ & ND & $1.03(0.98)$ & ND & ND & $0.22(0.38)$ & ND & ND \\
\hline
\end{tabular}

${ }^{1}$ Numbers represent means (SD; $\mathrm{n}=3$ ).

${ }^{2}$ Higher SD than the means occurred when the microbial group was absent from 1 or 2 of the triplicate cheese trials.

${ }^{3}$ No lipolytic bacteria were detected on tributyrin, triolein, and butterfat agar incubated at $8^{\circ} \mathrm{C}$.

${ }^{4} \mathrm{NSLAB}=$ Nonstarter lactic acid bacteria.

${ }^{5} \mathrm{ND}=$ Not detected.

Staphylococci were absent from PM cheeses but were present at 5.0 and $2.8 \mathrm{log} \mathrm{cfu} / \mathrm{g}$ at $1 \mathrm{~d}$, and at 4.2 and 1.5 log cfu/g at $168 \mathrm{~d}$ in RM and TM cheeses, respectively. Throughout ripening coagulase-positive staphylococci accounted for between 60 and $95 \%$ of the staphylococci detected in RM cheeses, indicative of the presence of Staphylococcus aureus.

Tributyrin-hydrolyzing bacteria capable of growth at $30^{\circ} \mathrm{C}$ were detected at $4.6,1.5$, and $0.2 \log \mathrm{cfu} / \mathrm{g}$ at $1 \mathrm{~d}$ and at 3.0, 2.7, and $0.2 \mathrm{log} \mathrm{cfu} / \mathrm{g}$ at $168 \mathrm{~d}$ in RM, TM, and PM cheeses, respectively. However, when plates were incubated at $8^{\circ} \mathrm{C}$, tributyrin-hydrolyzing bacteria were not detected in any of the cheeses. Triolein- or butterfat-hydrolyzing bacteria were not detected in any of the cheeses during ripening when agar plates were incubated at 8 or $30^{\circ} \mathrm{C}$. The majority of lipolytic colonies randomly isolated from RM, TM, and PM tributryin agar plates at $28 \mathrm{~d}$ were identified as gram-positive, catalase-positive cocci in RM and TM cheeses, and gram-positive rods in PM cheeses. Lipolytic bacteria previously isolated from Cheddar cheese belong predominantly to the genus Staphylococcus (Franklin and Sharpe, 1963; Gillies, 1971). In this study no correlation was observed between numbers of tributyrin-hydrolyzing bacteria detected and staphylococcal populations.

In agreement with Martley and Crow (1993), it is likely that NSLAB and other adventitious microflora in
PM cheeses entered the cheese from the environment, cheese-making equipment, or personnel during manufacture, whereas the more diverse adventitious bacteria in RM and TM cheeses would likely have originated from the milk (McSweeney et al., 1993).

\section{Starter Autolysis}

Increases in autolysis as detected by released $\mathrm{LDH}$ activity in cheese juice were monitored during the first $56 \mathrm{~d}$ of ripening (data not shown) when the starter lactic acid bacteria were the predominant population. No significant differences were observed in the LDH activity between the cheeses, but in agreement with O'Donovan et al. (1996), Hickey et al. (2006), and Sheehan et al. (2006), LDH activity increased significantly $(P<0.001)$ over ripening.

\section{Proteolysis}

In all cheeses, $\mathrm{pH}$ 4.6-SN, 5\% PTA-SN, and FAA increased significantly $(P<0.001)$ during ripening. Similar to results of previous studies (McSweeney et al., 1993; Shakeel-Ur-Rehman et al., 1999, 2000a,b), pasteurization of milk did not significantly affect the levels of primary proteolysis ( $\mathrm{pH}$ 4.6-SN) during ripening (data not shown). Significant differences were not ob- 

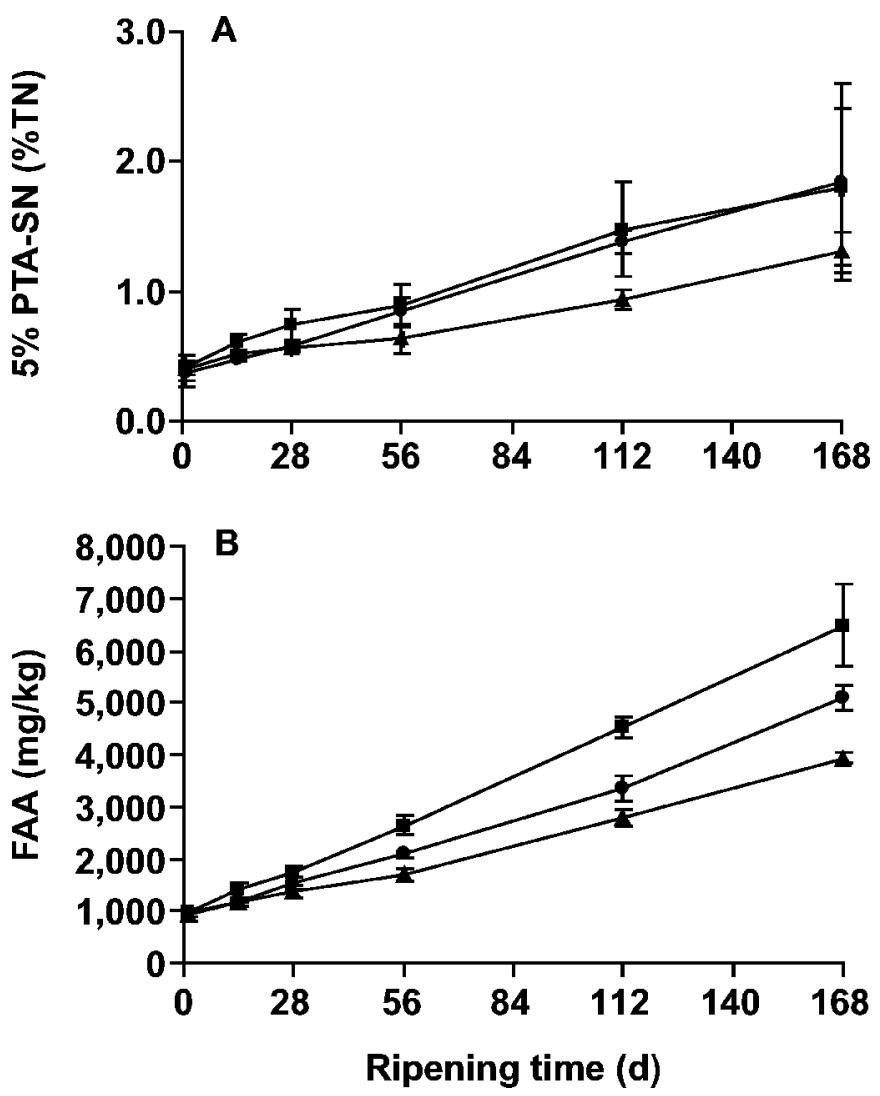

Figure 1. Proteolytic indices: A) 5\% phosphotungstic acid-soluble $\mathrm{N}$ (PTA-SN) as a percentage of total $\mathrm{N}(\mathrm{TN})$, and B) total FAA in Cheddar cheeses made from raw (ם), thermized $(\bullet)$, and pasteurized (A) milks. Error bars indicate $\pm 1 \mathrm{SD}(\mathrm{n}=3)$.

served between TM and RM cheeses for primary proteolysis as indicated by $\mathrm{pH} 4.6-\mathrm{SN}$. Similar to the results of Roy et al. (1997), levels of primary proteolysis were similar in TM and PM cheeses. In agreement with O'Keeffe et al. (1978), rennet appeared to be the principal agent responsible for primary proteolysis in all cheeses. Similar to trends noted for $\mathrm{pH}$ 4.6-SN, levels of 5\% PTA-SN were not significantly affected by severity of milk heat treatment (Figure 1). Therefore, it appears that in this study starter peptidases were the main contributors to formation of 5\% PTA-SN; however, at the latter stages of ripening, levels of 5\% PTA-SN were numerically higher in TM and RM cheeses, which may be due to the contribution of peptidases originating from the indigenous milk microflora or residual activity of indigenous milk proteinases.

Mean levels of FAA increased significantly $(P<0.001)$ in the order $\mathrm{PM}<\mathrm{TM}<\mathrm{RM}$ (Figure 1) and are in agreement with trends noted by Shakeel-Ur-Rehman et al. (1999, 2000a,b), who reported higher levels of FAA in RM compared with PM cheeses. Levels of FAA were similar in all cheeses up to $28 \mathrm{~d}$; thereafter, levels of FAA were significantly higher $(P<0.05)$ in RM cheeses compared with PM and TM cheeses. Thermized milk and PM cheeses had similar levels of FAA up to $56 \mathrm{~d}$; thereafter, levels were significantly higher $(P<$ $0.05)$ in TM cheeses. The greater accumulation of FAA in TM and RM cheeses (TM $<\mathrm{RM}$ ) may reflect the contribution of peptidases from indigenous microflora (Jensen et al., 1975; McSweeney et al., 1993). McSweeney et al. (1993) and Shakeel-Ur-Rehman et al. (1999, 2000a,b) suggested that peptidases from NSLAB might be responsible for higher levels of FAA in RM cheeses. Shakeel-Ur-Rehman et al. (2000a) suggested that, in addition to the numbers of NSLAB present in RM cheeses, the particular NSLAB strains might also influence FAA formation. The higher level of FAA in TM and RM cheeses might also be due to numerically higher levels of 5\% PTA-SN, which may reflect slight differences in levels of substrate for starter peptidases.

During ripening, mean levels of most individual FAA were significantly influenced by heat treatment except for Arg, Cys, Pro, and Ser (data not shown). Mean levels of Ala, Asp, Leu, Phe, and Thr were similar but significantly $(P<0.05)$ lower in TM and PM cheeses compared with RM cheeses. Mean levels of Glu, Gly, His, Ile, Lys, Met, and Val were significantly $(P<0.05)$ higher in RM compared with TM cheeses, which in turn were significantly higher than those in PM cheeses.

\section{FFA Profile and Lipolytic Activity in Cheese Milks}

The FFA profiles of the milks before and after incubation are shown in Table 5. Thermized milk and PM had similar and significantly lower $(P<0.05)$ levels of shortchain FFA (SCFFA, $\mathrm{C}_{4: 0}$ to $\mathrm{C}_{8: 0}$ ) and medium-chain FFA (MCFFA, $\mathrm{C}_{10: 0}$ to $\mathrm{C}_{14: 0}$ ) compared with RM. Significant differences were not observed between milks for long-chain FFA (LCFFA, $\mathrm{C}_{16: 0}$ to $\mathrm{C}_{18: 1}$ ). Overall, FFA were 43 and 50\% higher in RM than in TM and PM, respectively. The higher levels FFA in RM were most likely due to lipolysis by LPL during the pumping of the RM through the pasteurizer and into the vat because such conditions are known to enhance the action of LPL (Downey, 1980) by causing damage to the milk fat globule membrane and exposing the fat substrate.

Incubation of RM, TM, and PM to ascertain indigenous lipolytic activity resulted in a $6-, 5$-, and 1.5 -fold increase in the levels of total FFA (TFFA; Table 5). Increases in the levels of FFA in RM and TM during incubation was most likely due to LPL activity, with lower levels observed in TM as a result of partial inactivation of LPL. Although a significant increase in the levels of FFA was observed for PM after incubation, it was much lower than in TM and RM and may have 
Table 5. Concentrations of FFA (mg/kg of milk) in raw (RM), thermized (TM), and pasteurized (PM) milks before and after $15 \mathrm{~h}$ of incubation ${ }^{1}$

\begin{tabular}{|c|c|c|c|c|c|c|c|}
\hline \multirow[b]{2}{*}{$\mathrm{FFA}^{2}$} & \multicolumn{3}{|c|}{$\mathrm{RM}$} & \multicolumn{2}{|c|}{ TM } & \multicolumn{2}{|c|}{ PM } \\
\hline & $0 \mathrm{~h}$ & $15 \mathrm{~h}$ & & $0 \mathrm{~h}$ & $15 \mathrm{~h}$ & $0 \mathrm{~h}$ & $15 \mathrm{~h}$ \\
\hline $\mathrm{C}_{4: 0}$ & $15(7)^{\mathrm{b}}$ & 138 & $(32)^{\mathrm{a}}$ & $5(12)^{\mathrm{a}}$ & $30(22)^{\mathrm{a}}$ & $4(1)^{\mathrm{a}}$ & $4(1)^{\mathrm{a}}$ \\
\hline $\mathrm{C}_{6: 0}$ & $10(5)^{b}$ & 95 & $(24)^{\mathrm{a}}$ & $4(1)^{\mathrm{a}}$ & $23(19)^{\mathrm{a}}$ & $2(2)^{\mathrm{a}}$ & $3(0)^{\mathrm{a}}$ \\
\hline $\mathrm{C}_{8: 0}$ & $10(4)^{b}$ & 60 & $(15)^{\mathrm{a}}$ & $4(0)^{\mathrm{a}}$ & $20(14)^{\mathrm{a}}$ & $3(0)^{\mathrm{a}}$ & $3(0)^{\mathrm{a}}$ \\
\hline $\mathrm{C}_{10 \cdot 0}$ & $14(6)^{b}$ & 90 & $(30)^{\mathrm{a}}$ & $6(1)^{\mathrm{a}}$ & $29(22)^{\mathrm{a}}$ & $5(1)^{\mathrm{a}}$ & $5(1)^{\mathrm{a}}$ \\
\hline $\mathrm{C}_{12: 0}$ & $14(5)^{\mathrm{b}}$ & 77 & $(22)^{\mathrm{a}}$ & $7(1)^{\mathrm{a}}$ & $26(14)^{\mathrm{a}}$ & $6(1)^{\mathrm{a}}$ & $6(0)^{\mathrm{a}}$ \\
\hline $\mathrm{C}_{14: 0}$ & $28(10)^{b}$ & 158 & $(19)^{\mathrm{a}}$ & $14(4)^{b}$ & $54(20)^{\mathrm{a}}$ & $12(1)^{\mathrm{a}}$ & $14(1)^{\mathrm{a}}$ \\
\hline $\mathrm{C}_{16: 0}$ & $62(13)^{b}$ & 360 & $(79)^{\mathrm{a}}$ & $45(6)^{b}$ & $226(99)^{\mathrm{a}}$ & $41(15)^{\mathrm{b}}$ & $67(2)^{\mathrm{a}}$ \\
\hline $\mathrm{C}_{18: 0}$ & $13(10)^{\mathrm{a}}$ & 104 & $(62)^{\mathrm{a}}$ & $13(3)^{\mathrm{a}}$ & $51(9)^{\mathrm{a}}$ & $14(2)^{\mathrm{a}}$ & $22(1)^{\mathrm{a}}$ \\
\hline $\mathrm{C}_{18: 1}$ & $57(30)^{\mathrm{a}}$ & 250 & $(126)^{\mathrm{a}}$ & $32(24)^{\mathrm{a}}$ & $129(81)^{\mathrm{a}}$ & $26(7)^{\mathrm{a}}$ & $52(3)^{\mathrm{a}}$ \\
\hline SCFFA (sum of $\mathrm{C}_{4: 0}$ to $\mathrm{C}_{8: 0}$ ) & $35(16)^{b}$ & 293 & $(70)^{\mathrm{a}}$ & $12(2)^{\mathrm{a}}$ & $73(74)^{\mathrm{a}}$ & $9(1)^{\mathrm{a}}$ & $10(1)^{\mathrm{a}}$ \\
\hline MCFFA (sum of $\mathrm{C}_{10: 0}$ to $\mathrm{C}_{14: 0}$ ) & $56(21)^{b}$ & 325 & $(71)^{\mathrm{a}}$ & $26(6)^{\mathrm{a}}$ & $109(55)^{\mathrm{a}}$ & $21(1)^{\mathrm{a}}$ & $24(1)^{\mathrm{a}}$ \\
\hline LCFFA (sum of $\mathrm{C}_{16: 0}$ to $\mathrm{C}_{18: 1}$ ) & $133(52)^{\mathrm{b}}$ & 714 & $(262)^{\mathrm{a}}$ & $90(33)^{\mathrm{a}}$ & $406(186)^{\mathrm{a}}$ & $81(19)^{\mathrm{a}}$ & $137(7)^{b}$ \\
\hline Total (sum of $\mathrm{C}_{4: 0}$ to $\mathrm{C}_{18: 1}$ ) & $224(88)^{b}$ & 1331 & $(395)^{\mathrm{a}}$ & $128(39)^{\mathrm{a}}$ & $588(294)^{\mathrm{a}}$ & $111(24)^{b}$ & $173(6)^{\mathrm{a}}$ \\
\hline
\end{tabular}

${ }^{\mathrm{a}, \mathrm{b}}$ Values within rows not sharing a common superscript differ significantly, $P<0.05$.

${ }^{1}$ Numbers represent means $(\mathrm{SD} ; \mathrm{n}=3)$.

${ }^{2} \mathrm{SCFFA}=$ Short-chain FFA; MCFFA = medium-chain FFA; LCFFA = long-chain FFA.

arisen from physical agitation of the milks during incubation (Hadland and Hoye, 1974). Indeed it is well recognized that pasteurization extensively inactivates LPL: Andrews et al. (1987) found that heating milk for $15 \mathrm{~s}$ at 70 and $75^{\circ} \mathrm{C}$ resulted in residual LPL activities of 2 and $0 \%$, respectively. It is unlikely that heat-resistant bacterial lipases contributed to the production of FFA in RM, TM, or PM because psychrotrophic bacteria need to reach populations of $\sim 10^{6}$ to $10^{7} \mathrm{cfu} / \mathrm{mL}$ before significant lipolytic activity occurs (Ouattara et al., 2004). Psychrotrophic bacteria were at $10^{4} \mathrm{cfu} / \mathrm{mL}$ in RM before incubation and sodium azide was included to inhibit bacterial growth (Table 1).

\section{Lipolysis}

Comparison of samples of RM, TM, and PM with their equivalent cheeses at $\mathrm{d} 1$ indicated that approximately 50,26 , and $22 \%$ of TFFA present in the RM, TM, and $\mathrm{PM}$, respectively, were lost during the Cheddar cheese manufacturing process (data not shown). During manufacture of RM, TM, and PM cheeses, approximately 91, 78 , and $77 \%$ of the SCFFA, 47,7 , and $3 \%$ of the MCFFA, and 47,24 , and $27 \%$ of the LCFFA were lost to the whey, respectively. Loss of SCFFA and MCFFA to the whey was probably related to their water solubility. Higher losses of SCFFA, MCFFA, and LCFFA in the RM cheeses may be due to the higher level of these FFA in RM.

At d 1, levels of FFA in PM and TM cheeses were similar and significantly lower $(P<0.05)$ than in RM cheeses (Table 6); no significant differences were observed between TM and PM cheeses. The higher levels of FFA in RM cheeses at d 1 probably originated from higher levels of FFA in the milk and possibly LPL activity in the vat. It is unlikely that RM microflora contributed to lipolysis during cheese manufacture in the vat because their numbers were thought to be low. In addition, esterases from psychrotrophic bacteria were not detected on tributyrin, triolein, or butterfat agar incubated at $8^{\circ} \mathrm{C}$.

Mean levels of FFA increased significantly over ripening in all cheeses (Table 6). Mean levels of TFFA were significantly higher in RM cheeses compared with PM cheeses; however, no significant differences in TFFA were observed between TM and RM cheeses or between TM and PM cheeses. The higher levels of TFFA in RM Cheddar cheeses are in agreement with trends noted in previous studies (McSweeney et al., 1993; ShakeelUr-Rehman et al., 2000a,b). The rate of increase of SCFFA, MCFFA, and LCFFA were compared during ripening and no significant differences were observed for the rate of increase of MCFFA or LCFFA; however, the mean rate of increase of SCFFA increased significantly $(P<0.05)$ in the order $\mathrm{RM}<\mathrm{TM}<\mathrm{PM}$.

Some interesting differences were noted between SCFFA, MCFFA, and LCFFA in PM, TM, and RM cheeses over ripening. The percentage increase of SCFFA and MCFFA was in the order of PM $<$ TM $<$ $\mathrm{RM}$, with the LCFFA in the order of $\mathrm{RM}<\mathrm{TM}<\mathrm{PM}$. However, SCFFA, MCFFA, and LCFFA numerically increased in the order of $\mathrm{RM}<\mathrm{TM}<\mathrm{PM}$. This suggests that esterase activity predominated in PM cheeses and was most likely due to the starter bacteria (L. lactis. 303) because levels of NSLAB and other indigenous microflora did not reach sufficient numbers at all or 
Table 6. Free fatty acid $\left(\mathrm{mg} / \mathrm{kg}\right.$ of cheese) composition $\left(\mathrm{C}_{4: 0}\right.$ to $\left.\mathrm{C}_{18: 1}\right)$ and ANOVA of raw (RM), thermized (TM), and pasteurized (PM) milk Cheddar cheeses during ripening ${ }^{1}$

\begin{tabular}{|c|c|c|c|c|c|c|c|c|c|c|c|c|c|}
\hline Cheese & $\begin{array}{l}\text { Ripening } \\
\text { time, d }\end{array}$ & \multicolumn{12}{|c|}{ FFA } \\
\hline \multirow[t]{5}{*}{$\mathrm{RM}$} & 1 & $4(1)$ & $7(2)$ & $14(4)$ & $36(4)$ & $52(6)$ & 150 & (26) & 306 & (32) & 98 (11) & 211 (8) & $878(72)$ \\
\hline & 28 & $11(3)$ & 7 (1) & 11（1) & $48(6)$ & $74(7)$ & 132 & (11) & 379 & (35) & 88 & 202 (11) & $953(54)$ \\
\hline & 56 & $16(3)$ & 7 (1) & $12(0)$ & $50(4)$ & 78 (1) & 167 & (15) & 360 & $(46)$ & $92(6)$ & $222(6)$ & $1005(58)$ \\
\hline & 112 & $27(5)$ & $10(2)$ & $14(2)$ & $50(8)$ & $78 \quad(2)$ & 178 & (14) & 360 & (44) & 90 (10) & $253(22)$ & $1058(79)$ \\
\hline & 168 & 39 (1) & $14(1)$ & $15(10)$ & $57(4)$ & 73 (15) & 211 & (16) & 420 & (60) & $110(5)$ & $283(31)$ & $1223(108)$ \\
\hline & 28 & $9(0)$ & $6(1)$ & $9(0)$ & $41(2)$ & $62(2)$ & 109 & (5) & 322 & (18) & $70(6)$ & $178(20)$ & 805 (35) \\
\hline & 56 & $13(2)$ & 6 (1) & $10(1)$ & 42 (1) & $66(2)$ & 137 & (23) & 303 & (13) & $77(7)$ & $199(32)$ & 854 (55) \\
\hline & 112 & $23(2)$ & $8(1)$ & $11(1)$ & $43(4)$ & $68(6)$ & 155 & (9) & 318 & (27) & 74 (16) & $221(9)$ & 920 (37) \\
\hline & 168 & 34 (4) & 10 (1) & $12(1)$ & $46(0)$ & $65(2)$ & 171 & (9) & 341 & (17) & 89 (11) & 215 (27) & 984 (57) \\
\hline \multirow[t]{3}{*}{ PM } & 1 & $1(0)$ & $4(0)$ & 11（1) & $18(4)$ & $30(3)$ & 114 & (8) & 224 & (14) & $87(6)$ & $183(22)$ & $673(43)$ \\
\hline & 14 & 4 (1) & $5(0)$ & 12 (1) & 18 (5) & $33(6)$ & 119 & (4) & 229 & (10) & $87(6)$ & 173 & $681(20)$ \\
\hline & 28 & $8(0)$ & $4(1)$ & $8(0)$ & $36(3)$ & $58(3)$ & 93 & (2) & 269 & (28) & $71(6)$ & $158(20)$ & 705 (34) \\
\hline \multicolumn{2}{|c|}{ Treatment $^{2}$} & NS & * & $*$ & * & * & $*$ & & * & & * & $*$ & $*$ \\
\hline \multirow{2}{*}{\multicolumn{2}{|c|}{ Ripening time }} & $* * *$ & $* * *$ & $* * *$ & $* * *$ & $* * *$ & $* * *$ & & $* * *$ & & $* * *$ & $* * *$ & $* * *$ \\
\hline & & NS & NS & NS & NS & NS & NS & & $* * *$ & & NS & $* * *$ & $* * *$ \\
\hline
\end{tabular}

${ }^{1}$ Numbers represent means $(\mathrm{SD} ; \mathrm{n}=3)$.

${ }^{2}$ Treatment $=$ Raw, thermized, or pasteurized milk.

$* P<0.05 ; * * * P<0.001$.

until late in ripening, and LPL activity appeared to be essentially inactivated by pasteurization at $72^{\circ} \mathrm{C} \times 15$ s. However, the influence of other sources of lipolytic activity appears to increase in TM and in particular $\mathrm{RM}$ cheeses, due to increases in FFA content and to differences in the ratio of SCFFA, MCFFA, and LCFFA. The increase in MCFFA and LCFFA in TM and RM cheeses is most likely due to LPL activity because LPL is active toward tri- and diacylglycerols and has $s n-1$ and $s n-3$ specificity and will therefore cleave longer chain FFA (Reiter et al., 1969; Olivecrona and Bengtsson-Olivecrona, 1991). However, NSLAB (McSweeney et al., 1993; Shakeel-Ur-Rehman et al., 1999, 2000a,b) and indigenous microflora (Dovat et al., 1970; Gillies, 1971) might also contribute to lipolysis due to their high numbers, but because they have only esterase activity, they are unlikely to be responsible for the increase in MCFFA and LCFFA over ripening. Changes to the milk fat substrate induced by heat treatment (Dalgleish and Banks, 1991; Lopez et al., accepted) might also have influenced the accessibility of fat substrate to lipases and esterases during ripening of $\mathrm{PM}$ and TM cheeses.

In relation to individual FFA, mean levels of $\mathrm{C}_{4: 0}$ were similar in all cheeses during ripening indicating that the starter (L. lactis 303) was the most likely source for its production because it was the only lipolytic source that was similar in all cheeses. Mean levels of $\mathrm{C}_{8: 0}, \mathrm{C}_{10: 0}$, $\mathrm{C}_{14: 0}, \mathrm{C}_{18: 0}$, and $\mathrm{C}_{18: 1}$ were similar in $\mathrm{TM}$ and $\mathrm{PM}$ cheeses but significantly lower compared with RM cheeses. Raw milk cheeses had significantly higher mean levels of $\mathrm{C}_{6: 0}, \mathrm{C}_{12: 0}$, and $\mathrm{C}_{16: 0}$ compared with PM cheeses but no significant differences were observed between RM and TM cheeses for these FFA (Table 6). It is interesting to note that significant decreases $(P<0.001)$ in mean levels of $\mathrm{C}_{6: 0}, \mathrm{C}_{8: 0}, \mathrm{C}_{14: 0}$, and $\mathrm{C}_{18: 0}$ were observed in all cheeses during the first $28 \mathrm{~d}$ of ripening. This may have been due to catabolism of FFA (Collins et al., 2003).

The overall increase in FFA during ripening was modest in all cheeses compared with the increase in FAA, despite the potential lipolytic sources. The modest extent of lipolysis may be due to 1) immobilization of LPL in the casein network during cheese manufacture (Fox and Stepaniak, 1993); 2) a reduction in LPL activity during cheese manufacturing as a result of $\mathrm{pH}$ decrease or removal of LPL or LPL activators in the whey (Geurts et al., 2003; Choisy et al., 2000); 3) a lack of suitable mono- and diacylglycerols substrates for starter and NSLAB esterases (Holland et al., 2005); 4) the physical state of the milkfat substrate during ripening (Carunchia Whetstine et al., 2006); or 5) absorption of caseins and whey proteins onto the surface of fat globules during cheese production (Michalski et 
al., 2001; Lopez et al., accepted) thereby limiting access of lipolytic enzymes to the fat substrate.

\section{CONCLUSIONS}

Heat treatment of RM had a significant impact on the diversity and numbers of microflora in the resultant Cheddar cheeses. Milk heat treatment had no effect on $\mathrm{pH}$ 4.6-SN or 5\% PTA-SN formation; however, heat treatment reduced the levels of FAA during ripening, indicating that the indigenous proteolytic enzymes or proteases from the RM microflora influenced FAA production. Lipoprotein lipase activity in the RM was partially inactivated by thermization and extensively or wholly inactivated by pasteurization. Lipoprotein lipase was active in the vat and over the ripening period in RM and, to a lesser extent, in TM cheeses. Starter esterases were the major agents of lipolysis in PM cheeses and possibly in TM and RM cheeses. Indigenous milk microflora and NSLAB may have also contributed to lipolysis in TM and RM cheeses due to their presence at high levels from the start of ripening. The results of the study indicate that lipolytic activity of the starter esterases, indigenous microflora, and LPL appears limited due to impaired access to substrate or the physicochemical environment in cheese.

\section{ACKNOWLEDGMENTS}

This work was funded by the Department of Agriculture, Food and Forestry, Ireland, under the Food Industry Sub-Programme of EU Structural Funds.

\section{REFERENCES}

Andrews, A. T., M. Anderson, and P. W. Goodenough. 1987. A study of the heat stabilities of a number of indigenous milk enzymes. J. Dairy Res. 54:237-246.

Beuvier, E., K. Berthaud, S. Cegarra, A. Dasen, S. Pochet, S. Buchin, and G. Duboz. 1997. Ripening and quality of Swiss type cheese made from raw, pasteurized or microfiltered milk. Int. Dairy J. 7:311-323.

Beuvier, E., and S. Buchin. 2004. Raw milk cheeses. Pages 319-345 in Cheese: Chemistry, Physics and Microbiology. 3rd ed. General Aspects. Vol. 1. P. F. Fox, P. L. H. McSweeney, T. M. Cogan, and T. P. Guinee, ed. Elsevier, Academic Press, London, UK.

Carunchia Whetstine, M. E., M. A. Drake, B. K. Nelson, and D. M. Barbano. 2006. Flavour profiles of full-fat and reduced-fat cheese and cheese fat made from aged Cheddar with the fat removed a using novel process. J. Dairy Sci. 89:505-517.

Choisy, C., M. Desmazeaud, J. C. Gripon, G. Lamberet, and J. Lenoir. 2000 . The Biochemistry of ripening. Pages $83-151$ in Cheesemaking from Science to Quality Assurance. 2nd ed. A. Eck and J.-C. Gillis, ed. Lavoisier Publishing, Paris, France.

Collins, Y. F., P. L. H. McSweeney, and M. G. Wilkinson. 2003. Lipolysis and free fatty acid catabolism in cheese: A review of current knowledge. Int. Dairy J. 13:841-866.

Dalgleish, D. G., and J. M. Banks. 1991. The formation of complexes between serum proteins and fat globules during heating of whole milk. Milchwissenschaft 46:75-78.

Dovat, A. M., G. W. Reinbold, E. G. Hammond, and E. R. Vedamuthu. 1970. Lipolytic and proteolytic activity of enterococci and lactic group streptococci isolated from young Cheddar cheese. J. Milk Food Technol. 33:365-372.

Downey, W. K. 1980. Review of the progress of dairy science: Flavour impairment from pre- and post-manufacture lipolysis in milk and dairy products. J. Dairy Res. 47:237-252.

Driessen, F. M., and J. Stadhouders. 1975. Lipolysis in hard cheese made from pasteurized milk. IDF. Bull. No. 86. Int. Dairy Fed., Brussels, Belgium.

European Union. 1992. Directive 92/46ECC Council. Diario oficial de las Comunidades Europeas. Off. J. L 268:1-34.

Fox, P. F., and L. Stepaniak. 1993. Enzymes in cheese technology. Int. Dairy J. 3:509-530.

Franklin, J. G., and M. E. Sharpe. 1963. The incidence of bacteria in cheese milk and Cheddar cheese and their association with flavour. J. Dairy Res. 30:87-99.

Geurts, T. J., F. J. Lettink, and J. T. M. Wouters. 2003. Lipase in milk, curd and cheese. Milchwissenschaft 58:61-65.

Gilles, J., and R. C. Lawrence. 1973. The assessment of Cheddar cheese quality by compositional analysis. N.Z. J. Dairy Sci. Technol. 8:148-151.

Gillies, A. J. 1971. Significance of thermoduric organisms in Queensland Cheddar cheese. Aust. J. Dairy Technol. 26:145-149.

Gilmour, A., R. S. MacElhinney, D. E. Johnson, and R. J. Murphy. 1981. Thermisation of milk. Some microbiological aspects. Milchwissenschaft 36:457-461.

Griffiths, M. W. 1986. Use of milk enzymes as indices of heat treatment. J. Food Prot. 49:696-705.

Hadland, G., and T. Hoye. 1974. Bacterial activity and lipolysis in raw bulk milk during storage, as related to the keeping quality of the pasteurized milk. Pages 368-369 in Proc. XIX International Dairy Congress. Vol. 1 E. Int. Dairy Fed., Brussels, Belgium.

Hickey, D. K., K. N. Kilcawley, T. P. Beresford, E. M. Sheehan, and M. G. Wilkinson. 2006. Starter strain related effects on the biochemical and sensory properties of Cheddar cheese. Int. Dairy J. 16:679-690.

Holland, R., S.-Q. Liu, V. L. Crow, M.-L. Delabre, M. Lubbers, M. Bennett, and G. Norris. 2005. Esterase of lactic acid bacteria and cheese flavour: Milk fat hydrolysis, alcoholysis and esterification. Int. Dairy J. 15:711-718.

IDF. 1996. Milk. Determination of fat content (Röse-Gottlieb gravimetric method). IDF Standard 1D. Int. Dairy Fed., Brussels, Belgium.

IDF. 2001. Milk. Determination of nitrogen content - Part 2: Block digestion method. IDF Standard 20-2. Int. Dairy Fed., Brussels, Belgium.

IDF. 2004. Milk. Determination of casein-nitrogen content - Part 1: Indirect method. IDF Standard 29-1. Int. Dairy Fed., Brussels, Belgium.

Jensen, J. P., G. W. Reinbold, C. J. Washam, and E. R. Vedamuthu. 1975. Role of enterococci in Cheddar cheese: Proteolytic activity and lactic acid development. J. Milk Food Technol. 38:3-7.

Lau, K. Y., D. M. Barbano, and R. R. Rasmussen. 1991. Influence of pasteurization of milk on protein breakdown in Cheddar during aging. J. Dairy Sci. 74:727-740.

Lopez, C., B. Camier, and J. Y. Gassi. Developments of the milk fat microstructure during the manufacture and ripening of Emmental cheese observed by confocal laser scanning microscopy. Int. Dairy J. (accepted)

Martley, F. G., and V. L. Crow. 1993. Interactions between non-starter micro-organisms during cheese manufacture and ripening. Int. Dairy J. 3:461-484.

McSweeney, P. L. H., P. F. Fox, J. A. Lucey, K. N. Jordan, and T. M. Cogan. 1993. Contribution of the indigenous microflora to the maturation of Cheddar cheese. Int. Dairy J. 3:613-634.

Michalski, M. C., F. Michel, D. Sainmont, and V. Briard. 2001. Apparent $\zeta$-potential as a tool to assess mechanical damages to the milk fat globule membrane. Colloids Surf. B Biointerf.23:23-30.

O’Donovan, C. M., M. G. Wilkinson, T. P. Guinee, and P. F. Fox. 1996. An investigation of the autolytic properties of three lactococcal strains during cheese ripening. Int. Dairy J. 6:1149-1165. 
O'Keeffe, A. M., P. F. Fox, and C. Daly. 1978. Proteolysis in Cheddar cheese: Role of coagulant and starter bacteria. J. Dairy Res. 45:465-477.

Olivecrona, T., and G. Bengtsson-Olivecrona. 1991. Indigenous enzymes in milk. Pages 62-78 in Food Enzymology. Vol. 1. Fox, P.F. ed. Elsevier Applied Science, London, UK.

Ouattara, G. C., I. J. Joen, R. A. Hart-Thakur, and K. A. Schmidt. 2004. Fatty acids released from milk fat by lipoprotein lipase and lipolytic psychrotrophs. J. Food Sci. 69:659-664.

Reiter, B., Y. Sorokin, A. Pickering, and A. J. Hall. 1969. Hydrolysis of fat and protein in small cheeses made under aseptic conditions. J. Dairy Res. 36:65-76.

Rogosa, M., J. A. Mitchell, and R. F. Wiseman. 1951. A selective medium for isolation and enumeration of oral and fecal lactobacilli. J. Bacteriol. 62:132-133.

Roy, D., M. Pitre, L. Blanchette, L. Savoie, G. Bélanger, P. Ward, and J. L. Maubois. 1997. Monitoring proteolysis and cheese juice composition during ripening of Cheddar cheese made from microfiltered milk. Lait 77:521-541.

SAS Institute. 2003. User's Guide: Statistics. Version 9.1.3 ed. SAS Institute, Inc., Cary, NC.

Shakeel-Ur-Rehman, J. M. Banks, P. L. H. McSweeney, and P. F. Fox. 2000a. Effect of ripening temperature on the growth and significance of non-starter lactic acid bacteria in Cheddar cheese made from raw or pasteurised milks. Int. Dairy J. 10:45-53.

Shakeel-Ur-Rehman, P. L. H. McSweeney, J. M. Banks, E. Y. Brechany, D. D. Muir, and P. F. Fox. 2000b. Ripening of Cheddar cheese made from blends of raw and pasteurised milk. Int. Dairy J. 10:33-44.

Shakeel-Ur-Rehman, P. L. H. McSweeney, and P. F. Fox. 1999. A study on the role of the indigenous microflora of raw milk on the ripening of Cheddar cheese. Milchwissenschaft 54:388-393.

Sheehan, A., G. O'Cuinn, R. J. FitzGerald, and M. G. Wilkinson. 2006. Proteolytic enzyme activities in Cheddar cheese juice made using lactococcal starters of differing autolytic properties. J. Appl. Micro. 100:893-901.

Stepaniak, L., and E. O. Rukke. 2003. Thermization of milk. Pages 2619-2623 in Encyclopedia of Dairy Sciences. Vol. 4. H. Roginski, J. W. Fuquay, and P. F. Fox, ed. Academic Press, London, UK.

Terzaghi, B. E., and W. E. Sandine. 1975. Improved medium for lactic streptococci and their bacteriophages. Appl. Microbiol. 29:807813.

Wilkinson, M. G., T. P. Guinee, D. M. O'Callaghan, and P. F. Fox. 1994. Autolysis and proteolysis in different strains of starter bacteria during Cheddar cheese ripening. J. Dairy Res. 61:249-262.

Wittenberger, C. L., and N. Angelo. 1970. Purification and properties of a fructose-1, 6-diphosphate-activated lactate dehydrogenase from Streptococcus faecalis. J. Bacteriol. 101:717-724. 